\title{
USE OF ACTIVATED CLINOPTILOLITE FOR DIRECT DYE-CONTAINED WASTEWATER TREATMENT
}

\author{
Viktoria Kochubei $^{1}{ }^{\otimes}$, Svitlana Yaholnyk ${ }^{1}$, Mariana Bets $^{1}$, Myroslav Malovanyy ${ }^{1}$
}

https://doi.org/10.23939/chcht14.03.386

\begin{abstract}
This work reveals a method of complex thermal and chemical activation of natural clinoptilolite from Sokyrnytsky deposit. The chemical activation of a mineral was carried out by $\mathrm{HCl}$ solutions treatment at various ratios of liquid-to-solid phases. With the use of thermal and infrared (IR) spectroscopic analyses, the adsorption property of a natural and activated clinoptilolite has been examined for water vapor. The ability of complexly activated clinoptilolite to adsorb direct dyes from their aqua solutions has been investigated. The constants of isotherms of monomolecular adsorption by Langmuir have been determined. Activated clinoptilolite has been suggested to be used for the treatment of wastewater containing organic impurities.
\end{abstract}

Keywords: zeolite, thermal analysis, adsorption, direct dyes.

\section{Introduction}

The water resources potential of Ukraine provides a basis of social, ecological and economic well-being of the nation. Wastes from chemical, food, pulp, and paper industries are the main sources of contamination by organic substances, particularly by surface-active agents and dyes. The production of dyes is related with using a large amount of water. On average, manufacturing of 1 ton of dyes consumes approximately 100-225 tons of water. In fabrics dyeing, $10-40 \%$ of used dyes, depending on the type, come into wastewater [1]. Important is the assessment of surface water objects that are under the influence of contamination components effluents [2], and analysis of opportunities for natural purification of effluents that are filtered from accumulation pounds, in the "aeration nature zone - wastewater" system [3]. The existence of a large number of organic contaminants leads to the death of fish, forage resources in bodies of water, impairs the taste and smell of water, and inhibits water self-purification in reservoirs. One of the ways to prevent environment

\footnotetext{
${ }^{1}$ Lviv Polytechnic National University,

12, S. Bandera St., 79013 Lviv, Ukraine

vicvitkoch@gmail.com

(c) Kochubei V., Yaholnyk S., Bets M., Malovanyy M., 2020
}

pollution by wastewater is the application of modern efficient treatment technologies, such as ultrasound and vibration cavitation $[4,5]$, membrane technologies $[6,7]$, electrodialysis $[8,9]$, adsorbtion on natural sorbents of mineral $[10,11]$ and plant $[12,13]$ origin, as well as aerobic biological methods [14, 16]. An effective method of preventing surface water bodies pollution by hydrobionts is to collect and use them for the production of energy carriers (biogas, biodiesel) [17, 18].

The efficiency of wastewater treatment with natural adsorbents using an example of natural zeolites has been examined. Unlike carbon adsorbents, natural zeolites are cheap enough. They are characterized by high mechanical strength, chemical resistance and porosity. The specificity in properties of these adsorbents is postulated by the structure of a three-dimensional aluminosilicate framework and by the existence of a developed system of cavities and channels within which a complex of exchangeable cations and water molecules are retained. Owing to their unique features, natural zeolites are widely used in various industries [19].

However, in a number of cases natural zeolites (principally clinoptilolite) cannot be used for sewage treatment because of the pores in their structure which size is smaller than that of organic pollutants. Thus, the diameter of clinoptilolite channels can range from 0.38 to $0.62 \mathrm{~nm}$ whilst the sizes of solvated direct-dye ions are greater than $1 \mathrm{~nm}[20]$.

For controlling molecular sieve properties, zeolites are subjected to thermal and chemical activations. In the process of thermal activation (that may be usefully undertaken in a filtration process, the kinetics of which was given in [21]), free cations migrate into inaccessible areas of the zeolite framework. This allows for an increase in the size of channels and overcoming difficulties associated with a molecular sieve effect. Nevertheless, thermal activation is a reversible process. The activated zeolite rapidly reproduces its original structure by losing enhanced adsorption properties that were acquired [22]. Chemical treatment provides irreversible changes in the structure of zeolite, causes the decationation of samples by converting them to $\mathrm{H}^{+}$forms. Chemical activation is performed by using mineral acids. An increase in the acid concentration can initially lead to an improvement in the 
adsorption features of zeolite, and then can cause destruction of its three-dimensional framework.

Therefore, the aim of the work was to experimentally find a way of activating natural zeolite in order to obtain a highly effective adsorbent, which can be used to remove organic contaminants from wastewater.

\section{Experimental}

A naturally occurring zeolite, that is, a clinoptilolite (sample 1), a thermally activated clinoptilolite (sample 2) and a complexly (both thermally and chemically) activated clinoptilolite (samples 3 and 4) have been investigated in this work.

The natural clinoptilolite from Sokyrnytsky deposit was used for investigation. The chemical composition of mineral (wt \%) comprises $\mathrm{SiO}_{2} 70.21 ; \mathrm{Al}_{2} \mathrm{O}_{3} 12.27 ; \mathrm{Fe}_{2} \mathrm{O}_{3}$ 1.2; $\mathrm{FeO} 0.55 ; \mathrm{TiO}_{2}$ 0.14; $\mathrm{MnO} 0.073 ; \mathrm{P}_{2} \mathrm{O}_{5} 0.033 ; \mathrm{K}_{2} \mathrm{O}$ 3.05; $\mathrm{Na}_{2} \mathrm{O} 1.77 ; \mathrm{SO}_{3} 0.10 ; \mathrm{CaO}+\mathrm{MgO} 10.604$. formula:

The composition corresponds to the following $0.2 \mathrm{Na}_{2} \mathrm{O} \cdot 0.26 \mathrm{~K}_{2} \mathrm{O} \cdot 0.43 \mathrm{CaO} \cdot 0.2 \mathrm{MgO} \cdot 9.57 \mathrm{SiO}_{2} \cdot \mathrm{Al}_{2} \mathrm{O}_{3} \cdot 0.09 \mathrm{Fe}_{2} \mathrm{O}_{3}$. $0.25 \mathrm{~mm}$.

The particle size of natural clinoptilolite was

The thermally activated clinoptilolite was obtained by heating natural clinoptilolite in air. Thermal activation of clinoptilolite was carried out at the temperature of $573 \mathrm{~K}$ for $2 \mathrm{~h}$ [23].

In the process of complex activation, clinoptilolite samples have been pretreated with $5 \% \mathrm{HCl}$ solutions within twenty-four hours at the ratio of solid-to-liquid phases of 1:5 (sample 3) and 1:10 (sample 4). The samples were then kept in air at $573 \mathrm{~K}$.

The thermal analysis of clinoptilolite samples was done on a Q-1500 D derivatograph of system F. Paulik, J. Paulik and L. Erdey at the temperatures from 293 to $1273 \mathrm{~K}$. The samples were analyzed dynamically at the heating rate of $10 \mathrm{~K} / \mathrm{min}$ under atmosphere of air. The weight of samples 1 and 2 was equal to $500 \mathrm{mg}$ and that of samples 3 and 4 amounted to $400 \mathrm{~g}$. TG sensitivity was $100 \mathrm{mg}$, DTG sensitivity was equal to $500 \mu \mathrm{V}$, and that of DTA $100 \mu \mathrm{V} . \mathrm{Al}_{2} \mathrm{O}_{3}$ was used as a standard. Before conducting thermal studies, the clinoptilolite samples have been saturated with water vapor for two hours at room temperature and at the relative pressure of water vapor $p / p s=0.4$.

Registration of infrared spectra was recorded on Avatar 320 FT-1R device in the range of $4000-400 \mathrm{~cm}^{-1}$ in the form of $\mathrm{KBr}$ tablets.

The adsorption property of those clinoptilolite samples that underwent complex activation was investigated by using dyes:

Direct green (DG)

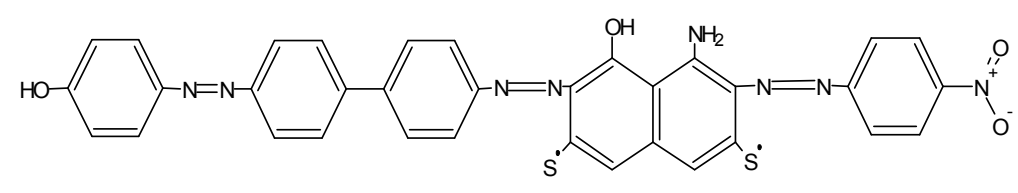

Direct violet (DV)

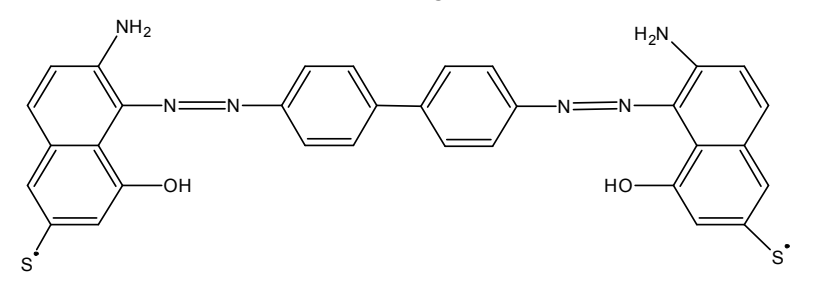

For the investigation of direct dyes adsorption, clinoptilolite of $0.62 \mathrm{~g}$ was mixed with $20 \mathrm{ml}$ of dye solution. The dye concentration in the solution was $50 \mathrm{~g} / \mathrm{m}^{3}$. The resulting suspension was shaken at AVU-6 for $12 \mathrm{~h}$ at the oscillation frequency of $100 \mathrm{~min}^{-1}$. The initial and equilibrium concentrations of dyes in the solution were determined using a photoelectric colorimeter KF-77. The suspension was precipitated until clinoptilolite was completely detached from the dye solution. The liquid phase was filtered off.

Dye adsorption by clinoptilolite samples was investigated in a region of concentrations below the critical concentration of micelle formation. The surface tension of dye aqueous solutions was measured by the ring method.

\section{Results and Discussion}

Thermal analysis is one of the main research techniques for zeolites. With this method, the nature of bound warter, the character of dehydration process on heating samples and their thermal stability are determined. Data from thermogravimetric (TG) and differential thermal analyses (DTA) give a deep insight into the nature of processes that occur in zeolite when heated.

Thermograms for the samples of clinoptilolite are shown in Figs. 1-4. The TG curves show a mass loss of samples on heating. The DTA curves determine the sign and define a quantity of the thermal effect. The curves of differential thermogravimetric analysis (DTG) are a result of TG curve differentiation, corresponding to the rate of mass loss of samples at an appropriate temperature. 
Thermolysis of the clinoptilolite samples comprises four stages. At the first stage, which occurs at the temperatures from 293 to $483 \mathrm{~K}$, the physically adsorbed moisture is released, which is followed by a rapid mass loss of the samples and a deep endothermic effect that appears on the DTA curve.

At the first stage, the ability of the clinoptilolite samples to adsorb is estimated by the loss of mass (Table 1). Thermolysis data reveal that sample 2 demonstrates higher absorption in comparison with sample 1. Such feature of sample 2 can be attributed to the thermal activation that involves diffusion of exchangeable cations in internal channels of the zeolite structure. This process is accompanied by the growth of crystalline interior of the mineral and enhanced ability to adsorb water molecules [24].

Complexly activated samples 3 and 4 exhibit greater adsorption property for water vapor as compared with samples 1 and 2 . Treating clinoptilolite with $\mathrm{HCl}$ solution leads to the removal of exchangeable cations $\mathrm{Na}^{+}$, $\mathrm{K}^{+}, \mathrm{Ca}^{2+}$ from its structure and to the conversion of clinoptilolite into the $\mathrm{H}^{+}$form. These changes cause a rise in the size of channels, making them more readily accessible to water molecules [25].

The second stage of thermolysis in the temperature range from 473 to $683 \mathrm{~K}$ fits with the discharge of water molecules that are coordinately linked with cations of the minerals crystalline lattice. This process is followed by the gradual mass loss of samples and by an endothermic effect on the DTA curve.
The third stage of thermolysis occurs at temperatures from 653 to $798 \mathrm{~K}$, revealing surface dehydroxylation due to splitting out of $\mathrm{OH}$ groups. The nature of activation is strongly pronounced as evidenced by the appearance of an insignificant endothermic maximum on the DTA curve within a given range of temperature.

At the fourth stage in the temperature range of $781-1273 \mathrm{~K}$ there is a destruction and amorphization of the zeolite crystal structure and completion of surface dehydroxylation. This process is followed by a significant endothermic effect that appears on the DTA curve [26].

Considering the mass loss at the third and fourth stages, the specific surface area of samples of clinoptilolite is calculated on the basis of Eq. (1) [20]:

$$
S_{\text {num }}=n S_{0} / \mathrm{m}
$$

where $S_{0}$ is an area corresponding to one chemisorbed water molecule $\left(S_{0}=0.2110^{-18} \mathrm{~m}^{2} /\right.$ molecule $) ; n$ is a quantity of chemisorbed water molecules; $m$ denotes the weight of a clinoptilolite sample, $\mathrm{kg}$.

The samples of activated clinoptilolite are noted for an interphase surface found to be more developed when compared with the sample of natural clinoptilolite. A specifically well-developed phase boundary is typical of sample 4 , which can be ascribed to changes caused by complex activation. Acid affects not only the cationization of the sample. Under the influence of $\mathrm{H}^{+}$ions clinoptilolite is partially dealuminated. Not only increases the volume of internal channels of the mineral, but a number of micropores and transition pores also appears [24].

Table 1

Results of thermolysis of thermally activated samples of clinoptilolite

\begin{tabular}{|c|c|c|c|c|c|c|c|}
\hline Sample & $\begin{array}{l}\text { Weight of } \\
\text { sample, mg }\end{array}$ & $\begin{array}{c}\text { Temperature } \\
\text { range, } \mathrm{K}\end{array}$ & $\begin{array}{l}\text { Mass } \\
\text { loss, mg }\end{array}$ & $\begin{array}{c}\text { Total mass } \\
\text { loss, mg }\end{array}$ & $\begin{array}{c}T_{\max } \text { of main } \\
\text { endothermic effect }\end{array}$ & $\begin{array}{c}\text { Specific surface } \\
\text { area, } \mathrm{m}^{2} / \mathrm{g}\end{array}$ & $\begin{array}{l}\text { Adsorption pro- } \\
\text { perty, } \mathrm{mmol} / \mathrm{g}\end{array}$ \\
\hline \multirow{4}{*}{1} & \multirow{4}{*}{500} & $293-473$ & 31 & \multirow{4}{*}{54} & \multirow{4}{*}{125} & \multirow{4}{*}{140.5} & \multirow{4}{*}{3.4} \\
\hline & & $473-673$ & 13 & & & & \\
\hline & & $673-781$ & 4.5 & & & & \\
\hline & & $781-1273$ & 5.5 & & & & \\
\hline \multirow{4}{*}{2} & \multirow{4}{*}{500} & $293-473$ & 42 & \multirow{4}{*}{68.5} & \multirow{4}{*}{160} & \multirow{4}{*}{154.5} & \multirow{4}{*}{4.6} \\
\hline & & $473-653$ & 15.5 & & & & \\
\hline & & $\begin{array}{l}653-793 \\
\end{array}$ & 6.5 & & & & \\
\hline & & $793-1273$ & 4.5 & & & & \\
\hline \multirow{4}{*}{3} & \multirow{4}{*}{400} & $293-473$ & 34 & \multirow{4}{*}{54} & \multirow{4}{*}{140} & \multirow{4}{*}{154} & \multirow{4}{*}{4.72} \\
\hline & & $473-475$ & 13 & & & & \\
\hline & & $\begin{array}{l}475-793 \\
\end{array}$ & 4 & & & & \\
\hline & & $793-1273$ & 4.5 & & & & \\
\hline \multirow{4}{*}{4} & \multirow{4}{*}{400} & $293-483$ & 37 & \multirow{4}{*}{64} & \multirow{4}{*}{162} & \multirow{4}{*}{199} & \multirow{4}{*}{5.13} \\
\hline & & $483-683$ & 16 & & & & \\
\hline & & $\begin{array}{l}683-798 \\
\end{array}$ & 4.5 & & & & \\
\hline & & $798-1273$ & 6.5 & & & & \\
\hline
\end{tabular}




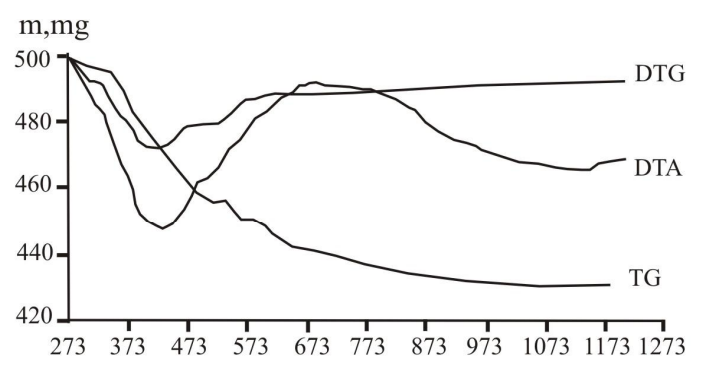

$\mathrm{T}, \mathrm{K}$

Fig. 1. Thermogram of sample 1

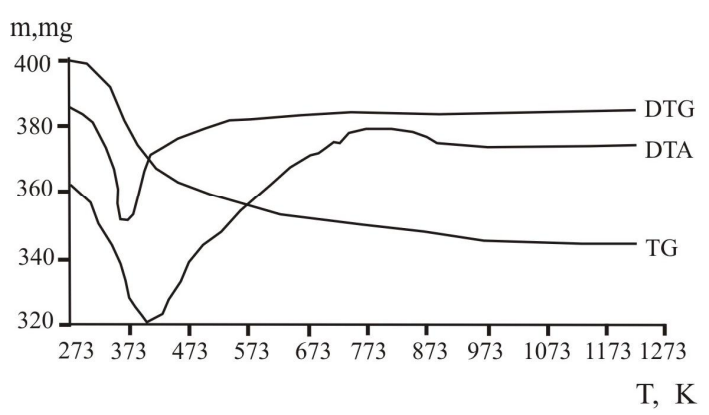

Fig. 3. Thermogram of sample 3

The effect of activation on physico-chemical properties of the clinoptilolite samples is confirmed by data from the IR spectroscopic analysis. The results of the said analysis for the investigated samples are represented in Figs. 5-8. A wide band that becomes apparent in IR spectra of samples in a high-frequency region of $3800-3500 \mathrm{~cm}^{-1}$ is referred to valence vibrations of $\mathrm{OH}$ groups of adsorbed water [27]. This water is retained on the surface of clinoptilolite by oxygen atoms due to hydrogen bonds. For the activated samples of clinoptilolite, this band is found to be deeper. The data obtained are supported by the results of thermal analysis (Table 1). The samples of activated clinoptilolite show a higher adsorption capacity for water vapor in comparison to the sample of natural clinoptilolite.

The band that appears in the IR spectrum of a clinoptilolite sample at $2359.82 \mathrm{~cm}^{-1}$ is associated with stretching vibrations of isolated hydroxyl groups that exist on the surface of sample 1. Similar bands on spectra of the samples of activated clinoptilolite are shifted to a region of higher frequencies. For sample 2, the band of stretching vibrations of isolated hydroxyl groups is shown at $2360.37 \mathrm{~cm}^{-1}$, for sample $3-$ at $2365.41 \mathrm{~cm}^{-1}$, and for sample 4 - at $2364.00 \mathrm{~cm}^{-1}$.

The band that is attributed to bending vibrations of $\mathrm{OH}$ groups is observed on the IR spectrum of the sample of natural clinoptilolite at $1635 \mathrm{~cm}^{-1}$. The bands for bending vibrations of $\mathrm{OH}$ groups of activated

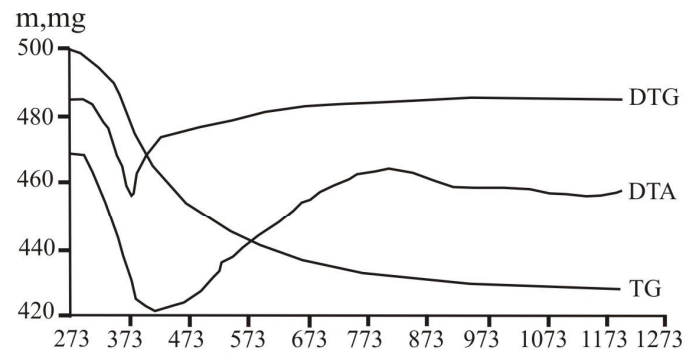

$\mathrm{T}, \mathrm{K}$

Fig. 2. T Thermogram of sample 2

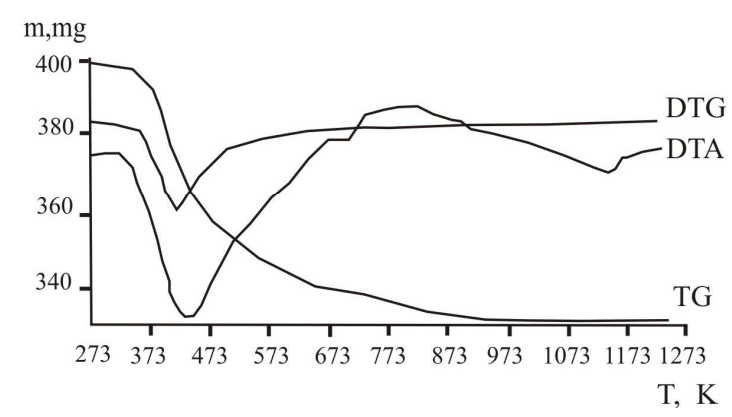

Fig. 4. Thermogram of sample 4

clinoptilolite samples are shifted to higher frequencies, and comparatively are more intense than the sample of natural clinoptilolite. For sample 2, this band is observed at $1636.79 \mathrm{~cm}^{-1}$, for complexly activated samples - at $1636.80 \mathrm{~cm}^{-1}$ (sample 3), and $1636.59 \mathrm{~cm}^{-1}$ (sample 4). The existence of a greater number of $\mathrm{OH}$ groups on the surface of the activated samples is confirmed by the thermal analysis data. In terms of the loss of mass as a result of the detachment of hydroxyl groups in the hightemperature region, the specific surface of the samples is identified. As compared to the samples of natural clinoptilolite, $S_{S}$ is greater for those of activated clinoptilolite.

The strong band that becomes apparent on the IR spectrum of natural clinoptilolite at low frequencies of $1054.96 \mathrm{~cm}^{-1}$ is attributed to the internal and external vibrations of ( $\mathrm{Si}, \mathrm{Al})-\mathrm{O}$ bonds of aluminosilicate framework of the mineral. For the samples of activated clinopillolite, this band is deeper and is shown at $1062 \mathrm{~cm}^{-1}$ (sample 2), $1050.34 \mathrm{~cm}^{-1}$ (sample 3) and $1082.30 \mathrm{~cm}^{-1}$ (sample 4). Considerable deepening of the bands of intratetrahedral vibrations on the spectra of the samples of complexly activated clinoptilolite indicates the partial decomposition of $\mathrm{Si}-\mathrm{O}-\mathrm{Al}$ linkages in samples 3 and 4. The decomposition of ( $\mathrm{Si}, \mathrm{Al})-\mathrm{O}$ bonds in samples 3 and 4 under the influence of $\mathrm{HCl}$ solutions causes the beginning of zeolite dealuminization, which is accompanied by an increasing number of channels in the 
structure of the mineral coupled with its specific surface. A change in the nature of the bands for natural clinoptilolite in the course of its activation is well consistent with thermolysis data. Complexly activated sample 4, obtained at the lower content of solid phase, is noted for the largest value of $S_{\mathrm{s}}$.

After conducted physical and chemical researches, it has been, therefore, found that as a result of complex activation of natural clinoptilolite it is possible to obtain a mineral with a developed specific surface and better ability to adsorb water molecules.

The samples of clinoptilolite after exposure to complex activation were researched for the ability to adsorb molecules of direct dyes.

A large quantity of water-soluble dyes referred to different types (acidic, basic, direct, etc.) is currently pro- duced. The ability of dye molecules to be adsorbed on the surface of a mineral essentially depends on their spatial arrangement, the existence of functional groups, and their ability to associate. Therefore, the effectiveness of the use of sorbents in the processes of water purification and in ensuring water resources security largely depends on a dye type.

Adsorption of dyes on the surface of minerals may occur under the influence of intermolecular forces that are physical in nature. The adsorption of direct dyes on the surface of complexly activated clinoptilolite can also take place under the effect of forces of chemical nature not least because of the formation of ionic bonds that arise between the $\mathrm{H}^{+}$form of a modified clinoptilolite and an organic ion of a dye [25].

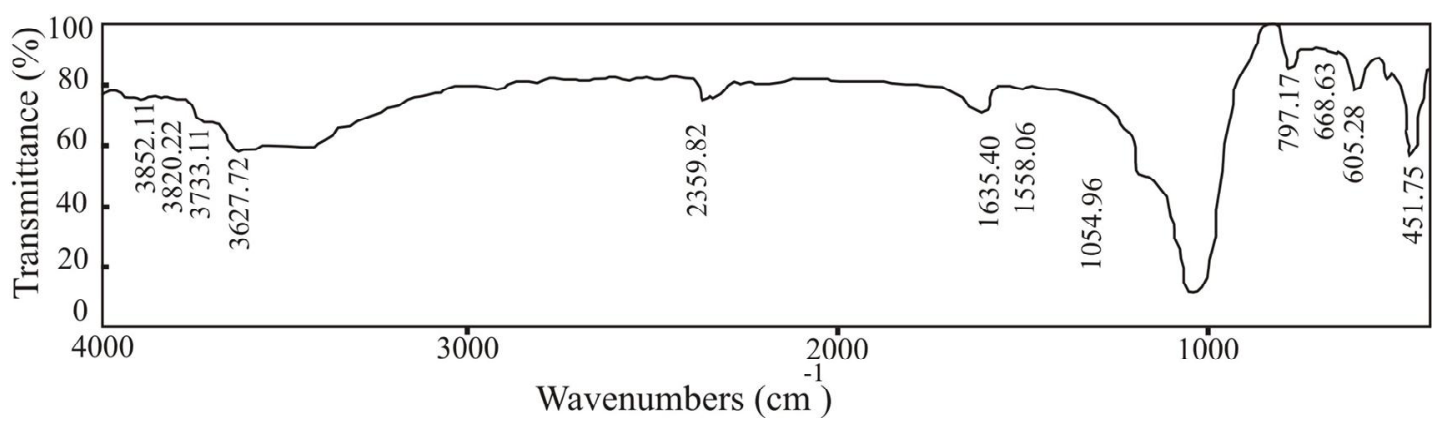

Fig. 5. IR spectrum of sample 1

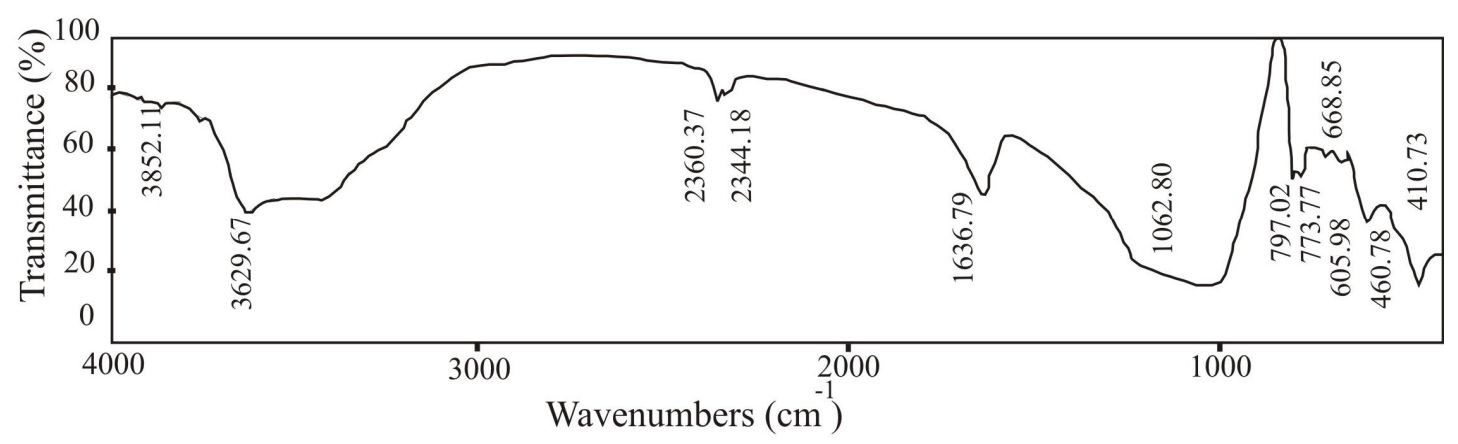

Fig. 6. IR spectrum of sample 2

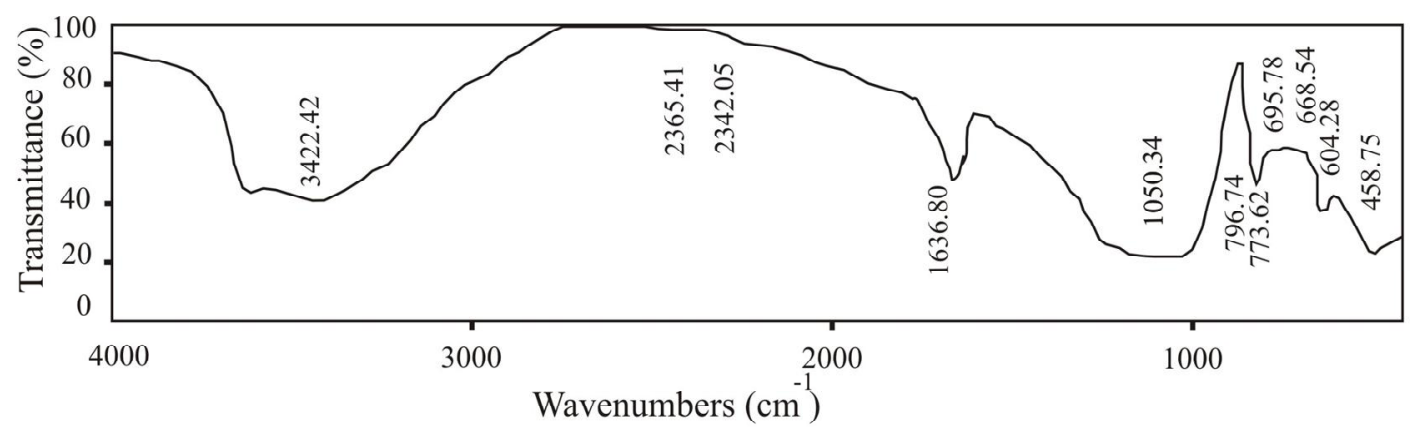

Fig. 7. IR spectrum of sample 3 


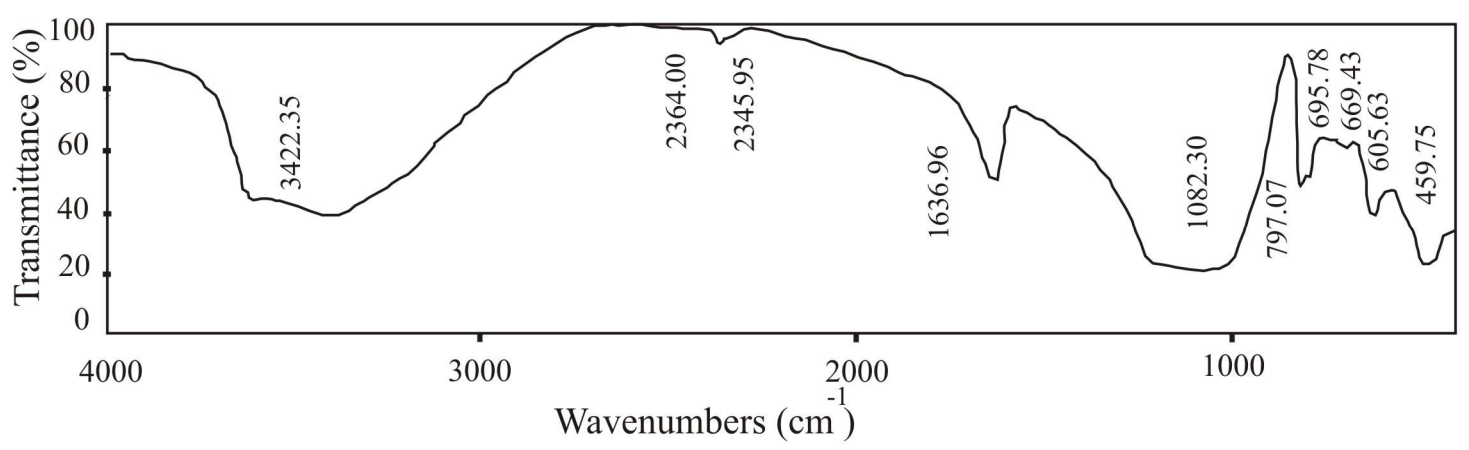

Fig. 8. IR spectrum of sample 4

The ability of direct dyes to be adsorbed onto the surface of complexly activated clinoptilolite samples was proved by using the IR spectroscopic analysis.

On the spectrum of samples 3 and 4 that contained an adsorbed dye of DG and DV in the region of 3600 $3400 \mathrm{~cm}^{-1}$ we observe the appearance of additional bands corresponding to the symmetric and asymmetric stretching vibrations of the $\mathrm{N}-\mathrm{H}$ bonds that are present in amino groups of the dye [28]. The appearance of additional bands in the region of $1600-1500 \mathrm{~cm}^{-1}$ is referred to bending vibrations of the $\mathrm{N}-\mathrm{H}$ bonds of the $\mathrm{NH}_{2}$ groups. The bands observed at $1500-1480 \mathrm{~cm}^{-1}$ correspond to the vibrations of the $-\mathrm{C}=\mathrm{C}-$ bonds of the aromatic ring of the dye. On IR spectra of samples of activated clinopilolite there is an increase in band intensity in the region of $1200-1000 \mathrm{~cm}^{-1}$ caused by stretching vibrations of the $\mathrm{C}-\mathrm{N}$ bonds of the adsorbed dye [29].

Figs. 9 and 10 show the adsorption isotherms of DG and DV dyes on the surface of samples 3 and 4 of activated clinoptilolite. The values of dye adsorption were defined according to Eq. (2):

$$
A=\frac{C_{i}-C_{e}}{m} V
$$

where $C_{i}$ and $C_{e}$ are initial and equilibrium concentrations of dyes in the solution, respectively, $\mathrm{mmol} / \mathrm{m}^{3} ; V$ is a

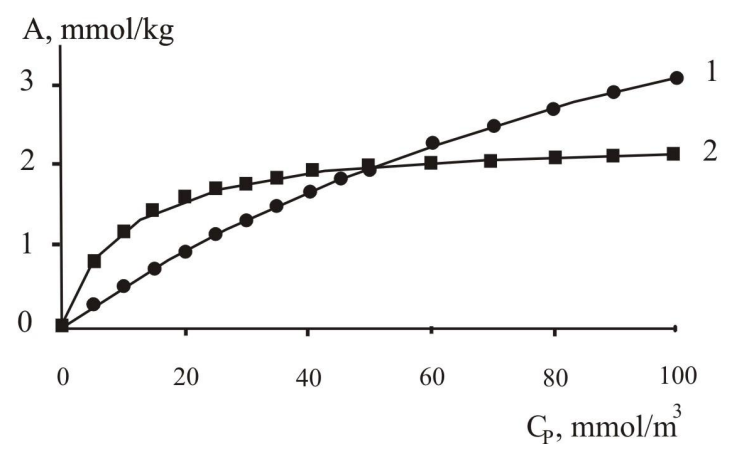

Fig. 9. Adsorption isotherms of dyes on the surface of sample 3: direct violet (1) and direct green (2) volume of dye solution, $\mathrm{m}^{3} ; m$ denotes the weight of activated clinoptilolite sample, $\mathrm{kg}$.

The dye adsorption was investigated in a concentration region below the critical concentration for micelle formation $\left(C_{\mathrm{CMM}}\right)$. The latter was identified by the break in the curve $\sigma=f(\ln c)$. The critical concentration for micelle formation for the solution of direct green dye and for that of direct violet was 370 and $174 \mathrm{mmol} / \mathrm{m}^{3}$, respectively.

As it can be seen from Figs. 9 and 10, the adsorption of direct dyes on the samples of activated clinoptilolite follows well the theory of Langmuir monomolecular adsorption. By linearizing the equation of the Langmuir adsorption isotherm, the constants were found $-\mathrm{a}$ limit value of the monomolecular adsorption $A_{\infty}$ and the constant of adsorption-desorption equilibrium $K$ (Table 2).

Sample 4 has a comparatively better adsorption property for direct dyes than sample 3. Through the whole range of concentrations under investigation, the adsorption value for this sample is higher as compared to sample 3 (Figs. 9 and 10). Sample 4 is characterized by larger values of constants of the adsorption-desorption equilibrium. The results of the adsorption property of the samples are in good agreement with the data from the thermal and IR spectroscopic analyses. Sample 4 has the most effective surface of phase boundary (Table 1).

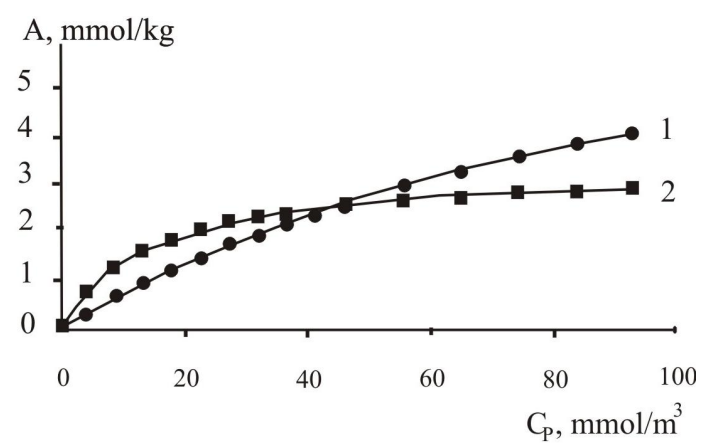

Fig. 10. Adsorption isotherms of dyes on the surface of sample 4: direct violet (1) and direct green (2) 
Langmuir isotherm constants

\begin{tabular}{|c|c|c|c|}
\hline Sample & Dye & $A_{\infty}, \mathrm{mmol} / \mathrm{kg}$ & $K, \mathrm{~kg} / \mathrm{mmol}$ \\
\hline 3 & DG & 2.35 & 0.0100 \\
\hline 4 & DG & 3.50 & 0.0594 \\
\hline 3 & DV & 7.50 & 0.0071 \\
\hline 4 & DV & 9.53 & 0.0076 \\
\hline
\end{tabular}

Variations in values of $A_{\infty}$ and $K$ of direct dyes can be ascribed to the fact that the nature of direct dyes affects their ability to be adsorbed on the surface of zeolite. Dye molecules of DG and DV have various amounts of hydrophilic groups able to participate in the formation of solvates with solvent molecules. Dye molecules of DG are more susceptible to solvation in aqueous solution than those of DV. This may explain lower values of $A_{\infty}$ of the DG dye when compared with the DV dye as well as the rate of curves of adsorption isotherms of dyes. For the DG dye, the adsorption value rapidly increases in the lowconcentration region when filling large zeolite pores and gradually rises in the region of high concentrations. In the said region, the DV dye exhibits a better adsorption capacity owing to the smaller size of solvates that can penetrate the adsorbent finer pores.

\section{Conclusions}

As a result of the performed physico-chemical studies it has been proved that in the process of the complex (thermal and chemical) activation of clinoptilolite the mineral with enhanced adsorption features has been obtained. Comprehensive application of chemical and thermal treatment brings about irreversible changes in the structure of zeolite, which is followed by the growth of its specific surface. The transition of clinoptilolite into the $\mathrm{H}^{+}$form, which is followed by an irreversible clearance of an interior of the mineral, enables it to adsorb ions of direct dyes.

The investigation results make it possible to assert that complexly activated clinoptilolite can be used in water purification processes. For this reason, this sorbent is recommended for the absorption of surfactants from wastes of chemical, pulp and paper industries.

\section{References}

[1] Meerbergen K., Willems K., Dewil R. et al.: J. Biosci. Bioeng., 2018, 4, 448. https://doi.org/10.1016/j.jbiosc.2017.11.008 [2] Kulikova D., Pavlychenko A.: Sci. Bull. Nat. Mining Univ., $2016,4,62$.
[3] Pavlichenko A., Kroik A.: Sci. Bull. Nat. Mining Univ., 2013, 5, 93.

[4] Starchevskyy V., Bernatska N., Typilo I., Khomyshyn I.: Chem. Chem. Technol., 2017, 11, 358.

https://doi.org/10.23939/chcht11.03.358

[5] Mason T., Cobley A., Graves J.: Ultrason. Sonochem., 2011, 18, 226. https://doi.org/10.1016/j.ultsonch.2010.05.008

[6] Goncharuk V., Kucheruk D., Balakina M., Dul'neva T.: J. Water Chem. Technol., 2009, 31, 396.

https://doi.org/10.3103/S1063455X09060083

[7] Seminska O., Kucheruk D., Balakina M., Goncharuk V.: J.

Water Chem. Technol., 2016, 38, 67.

https://doi.org/10.3103/S1063455X16010070

[8] Shmandiy V., Bezdeneznych L., Kharlamova O. et al.: Chem.

Chem. Technol., 2017, 11, 242.

https://doi.org/10.23939/chcht11.02.242

[9] Gomelya M., Grabitcenko V., Radovenchik V., Makarenko

I.: Visnyk Nats. Techn. Univ. Ukrainy Kyiv. Polytech. Inst., 2017, 1, 58.

[10] Malyovanyy M., Sakalova G., Chornomaz N., Nahurskyy O. Chem. Chem. Technol., 2013, 7, 198.

[11] Vasylechko V., Korpalo Ch., Gryshchouk G.: Solid State Phenom., 2015, 230, 8.

https://doi.org/10.4028/www.scientific.net/SSP.230.8

[12] Danchenko Y., Andronov V., Kariev A. et al.: East. Eur. J.

Enterprise Technol., 2017, 12, 20 https://doi.org/10.15587/17294061.2017.111350

[13] Bezdeneznych L., Alekseeva T.: Ekolohichna Bezpeka, 2009, 6, 54 .

[14] Malovanyy M., Zhuk V., Sliusar V. et al.: East Eur. J. Adv. Technol., 2018, 1, 23. https://doi.org/10.15587/1729-

4061.2018.122425

[15] Malovanyy M., Shandrovych V., Malovanyy A. et al.: J. Chem., 2016, 2016, 9. https://doi.org/10.1155/2016/6874806

[16] Malovanyy M., Moroz O., Hnatush S., et al.: J. Ecol. Eng., 2019, 20, 8. https://doi.org/10.12911/22998993/94917/

[17] Malovanyy M., Nikiforov V., Kharlamova O., et al.: Chem. Chem. Techol., 2016, 10, 251.

https://doi.org/10.23939/chcht10.02.251

[18] Nykyforov V., Malovanyy M., Kozlovska T. et al.: East.-Eur. J. Enterprise Technol., 2016, 10, 11. https://doi.org/10.15587/17294061.2016.79789.

[19] Sanytsky M., Kropyvnytska T., Kruts T. et al.: Key Eng. Mater., 2018, 761, 193.

https://doi.org/10.4028/www.scientific.net/KEM.761.193

[20] Vasylechko V., Gryshchouk G., Zakordonskiy V. et al.: Chem. Cent. J., 2015, 9, 45. https://doi.org/10.1186/s13065-015-0118-z [21] Matkivska I., Gumnytskyi Y., Atamanyuk V.: Chem. Chem. Technol., 2014, 8, 395. 
[22] Oszczudlowski J., Witkiewicz Z., Andronikaszwili T., Krason J.: $3^{\text {rd }}$ West Ukrainian Symposium on Adsorption and Chromatography, Ukraine, Lviv 2003, 30.

[23] Yaholnyk S., Kochubei V., Trotskyy V., Chanyk Ja.: Teoriia i Praktyka Suchasnoho Pryrodoznavstva. Ukraine, Kherson 2007, 96. [24] Zakordonskyi V., Vasylechko V., Stashchuk P., Hryshchuk H.: Visnyk Lviv. Univ., 2004, 44, 247.

[25] Oszczudlowski J., Choma J.: XXXV Kolokwium Katalirycznyy, Poland, Krakow 2003, 133.

[26] Homonai V., Milovych S., Holub N.: Pratsi Uzhhorod. Univ., 2001, 6, 187.

[27] Holos I., Shelepeten L., Chaban I., Hass R.: 2 Sympozium z Adsorbtsii ta Khromatohrafii, Ukraine, Lviv 2000, 221.

[28] Stashchuk P., Danielkevych T., Maidan M., Kovalska-Ternes M.: 2 Sympozium z Adsorbtsii ta Khromatohrafii, Ukraine, Lviv 2000, 232.

[29] Chmylenko F., Zhuk L.: Spektrofotometrychni Metody Analizu. DNU, Dnipropetrovsk 2002.

Received: April 25, 2018 / Revised: May 24, 2018 / Accepted: September 12, 2018

\section{ВИКОРИСТАННЯ АКТИВОВАНОГО КЛИНОПТИЛОЛІТУ ДЛЯ ОЧИЩЕННЯ СТІЧНИХ ВОД ВІД ПРЯМИХ БАРВНИКІВ}

Анотація. Запропоновано метод комплексної термічної та хімічної активачії природного клиноптилоліту Сокирницького родовища. Хімічну активацію мінералу проводили внаслідок оброблення розчинами $\mathrm{HCl}$ за різного співвідношення рідкої та твердої фаз. 3 використанням термічного та ІЧ-спектроскопічного аналізів досліджена адсорбиійна здатність природного та активованого клиноптилоліту відносно парів води. Досліджена здатність комплексно активованого клиноптилоліту адсорбувати прямі барвники із їх водних розчинів. Визначені константи ізотерми мономолекулярної адсорбиії Ленгмюра. Запропоновано застосовувати активований клиноптилоліт для очищення стічних вод від органічних забруднень.

Ключові слова: цеоліт, термічний аналіз, адсорбиія, прямі барвники. 